Original Research Paper

\title{
Pemanfaatan Ekstrak Rumput Laut Sebagai Pupuk Organik Pada Pertanian Lahan Sempit Di Desa Lepak Lombok Timur
}

\author{
Mursal Ghazali $^{*}$, Evy Aryanti $^{1}$, Rina Kurnianingsih ${ }^{1}$, Sunarpi $^{1}$ \\ ${ }^{1}$ Program Studi Biologi Fakultas Matematika dan Ilmu Pengetahuan Alam Universitas Mataram
}

*Corresponding Author: Mursal Ghazali, Program Studi Biologi Fakultas Matematika dan Ilmu Pengetahuan Alam Universitas Mataram, Indonesia;

Email: mursalghazali@unram.ac.id

\begin{abstract}
Abstrak: Pertanian merupakan sektor yang memiliki peranan yang sangat penting bagi masyarakat Indonesia. Hal ini dikarenakan masyarakat Indonesia sebagian besar memanfaatkan pertanian untuk memenuhi kebutuhan sehari-hari. Namun setiap tahun luas lahan pertanian terus mengalami penurunan, akibat alih fungsi lahan. Disisi lain, jumlah penduduk terus mengalami peningkatan. Peningkatan jumlah penduduk menumbuhkan kesadaran untuk memanfaatkan lahan yang sempit untuk bercocok tanam. Selain itu, perlu dilakukan upaya untuk penyadaran kepada masyarakat untuk menggunakan pupuk organik ramah lingkungan yang salah satunya ialah penggunaan ekstrak Sargassum sp. Kegiatan ini dilaksanakan selama 4 bulan yaitu mulai Agustus sampai dengan November 2017. Kegiatan pengabdian masyarakat dilakukan melalui dua metode yaitu melalui diskusi kelompok dan partisipatif. Pada saat diskusi kelompok disampaikan tentang pemanfaatan lahan pekarangan dan potensi pemanfaatan esktrak Sargassum sp serta penggunaan kotoran ternak kambing sebagai media tana. Sedangkan pada metode partisipatif, masyarakat dibagikan pot percobaan sebagai media tanaman untuk diaplikasikan oleh masyarakat sendiri. Hasil kegiatan pengabdian menunjukkan bahwa masyarakat sangat antusias mengikuti kegiatan diskusi, hal ini disebabkan karena Sargassum sp bukan jenis tumbuhan yang asing, tetapi mereka baru tahu bahwa tumbuhan tersebut dapat dijadikan sebagai pupuk. Selain itu, hasil pemeliharaan yang dilakukan oleh masyarakat sebagian menunjukkan hasil yang positif dan sebagaian yang lain tidak berhasil. Ketidakberhasilan disebabkan karena banyak faktor diantaranya: dimakan ayam dan kambing.
\end{abstract}

Kata kunci: Musim Kering, Lahan Sempit dan Sayuran

\section{Pendahuluan}

Pertanian merupakan sektor yang memiliki peranan yang sangat penting bagi masyarakat Indonesia. Hal ini dikarenakan masyarakat Indonesia sebagian besar memanfaatkan pertanian untuk memenuhi kebutuhan sehari-hari maupun sebagai sumber penghasilan tetap. Sampai saat ini, sebagian besar petani Indonesia masih memanfaatkan lahan yang luas sebagai lahan pertanian. Namun setiap tahun luas lahan pertanian terus mengalami penurunan, akibat alih fungsi lahan (Kaputra, 2013). Disisi lain, jumlah penduduk terus mengalami peningkatan. Penurunan luasan lahan pertanian serta peningkatan jumlah penduduk menumbuhkan kesadaran untuk memanfaatkan lahan yang sempit untuk bercocok tanam. Pertanian lahan sempit mendapat perhatian dari sebagian masyarakat baik di negara maju maupun negara berkembang, khususnya mereka yang sangat memperhatikan kualitas kesehatan, baik kesehatan manusia maupun lingkungan.

Sistem pertanian lahan sempit semakin mendapat perhatian di Indonesia akibat terjadinya kerawanan pangan. Kementan mencatat sebanyak 100 kabupaten dari 349 kabupaten di Indonesia berpotensi rawan pangan. Ini artinya bahwa sekitar 27\% kabupaten di Indonesia berpotensi rawan pangan. Potensi ini terjadi akibat tingginya kebutuhan pangan tanpa didukung oleh budidaya tanaman pangan dan aksessibilitas yang rendah terhadap bahan pangan tersebut (Ashari et al. 2012). Kerawanan pangan erat kaitannya dengan ketahanan pangan keluarga. Menurut Saleim (2011), 
kerawanan pangan adalah kondisi tidak tercapainya ketahanan pangan di tingkat wilayah maupun rumah tangga/individu.

Kerawanan pangan ini sebenarnya dapat diatasi dengan memanfaatkan lahan secara maksimal, termasuk lahan sempit seperti pekarangan. Lahan sempit pekarangan dapat dimanfaatkan sebagai lahan pertanian dengan memadukan pola pertanian tradisional dengan ilmu pertanian modern yang terus berkembang (Siswati 2012). Penggunaan lahan sempit untuk pertanian sangat mudah untuk dikontrol sehingga sangat memungkinkan pertanian dengan menerapkan pertanian organik. Pertanian organik didefinisikan sebagai Sistem produksi pertanian yang berazaskan daur ulang secara hayati. Daur ulang hara dapat melalui sarana limbah tanaman dan ternak, serta limbah lainnya yang mampu memperbaiki status kesuburan dan struktur tanah Sutanto (2002). Pertanian organik lahan sempit memberikan keungguan produk bermutu, bebas bahan kimia serta tahan lama. Bahan organik sebagai bahan tanam untuk pertanian lahan sempit sangat melimpah bahkan jika tidak dimanfaatkan akan menjadi limbah lingkungan yang berpotensi membahayakan kesehatan masyarakat itu sendiri. Selain itu, sumber pupuk organik perangsang pertumbuhan dari ekstrak tumbuhan juga sangat melimpah. Salah satu sumber yang telah dimanfaatkan dan memiliki zat pengatur tumbuh yang tinggi ialah Sargassum sp (Nikmatullah, A.et.al, 2014).

Inisiasi pertanian lahan sempit bermula dari kelangkaan ketersediaan sayuran pada musim kemarau serta tingginya harga cabai tahun ini. Kelangkaan sayur pada musim kemarau merupakan fenomena yang sangat umum terjadi setiap tahun di Desa Lepak Kecamatan Sakra Timur. Hal ini disebabkan karena pada musim kemarau terjadi kekeringan yang menyebabkan kematian pada sayuran yang ditanam dilahan persawahan. Oleh sebab itu, perlu dilakukan pemindahan usaha tani persawahan menjadi pertanian lahan sempit. Pertanian ini dpat dilakukan dengan terkontrol dan hemat air. Dengan usaha ini paling tidak kebutuhan sayuran selama musim kemarau dapat terpenuhi.

\section{Metode Pelaksanaan}

Desa Lepak merupakan salah satu desa yang terdapat di Kecamatan Sakra Timur Kabupaten
Lombok Timur. Sumber mata pencaharian masyarakat yang ada di Desa Lepak pada umumnya adalah sebagai petani, sebagian kecil sebagai pegawai negeri sipil, pedagang dan peternak. Lahan pertanian sebagian besar merupakan lahan persawahan. Lahan-lahan ini umunya dapat ditanami hanya dua kali dalam setahun, yaitu pada musim hujan (tanaman padi) dan pada akhir musim hujan/awal musim kemarau (tembakau). Selebihnya, lahan pertanian dibiarkan menganggur. Oleh Sebab itu, untuk mendapatkan hasil yang maksimal, maka diperlukan strategi pendekatan yang sesuai untuk mendapatkan maksimal. Beberapa strategi pendekatan yang dilakukan ialah: 1. Melakukan transfer ilmu pengetahuan tentang pemananfaatan lahan sempit, potensi penggunaan Sargassum sp sebagai pupuk dan pemanfaatan kotoran kambing sebagai media tanam. Metode transfer ilmu pengetahuan dilakukan melalui diskusi kelompok atau yang dikenal dengan istilah FGD (Forum Group Discussion). 2. Memberikan kesempatan kepada masyarakat untuk berpartisipasi aktif terlibat dalam kegiatan pengabdian. Pada metode kedua ini, masyarakat diberikan pot yang telah ditanami beberapa jenis sayur untuk dipelihara sendiri. Jenis sayur yang dipeliharan diantaranya yaitu terung, sawi, tomat dan cabai rawit.

\section{Hasil Dan Pembahasan}

\section{Diskusi Kelompok}

Pengembangan masyarakat dalam pembangunan diartikan sebagai pelaku dan penerima manfaat. Dengan demikian masyarakat dapat berperan aktif melibatkan diri (dalam diskusi maupun penerapan) dalam berbagai kegitan termasuk dalam kegiatan pengabdian yang dilakukan. Pada kegiatan pengabdian ini langkah pertama yang dilakukan ialah kegiatan diskusi kelompok yang bertujuan untuk mentransfer ilmu pengetahuan kepada masyarakat. Kegiatan transfer ilmu pengetahuan ini merupakan salah satu langkah yang dilalui untuk meningkatkan pemahaman dan pengetahuan masyarakat tentang penggunaan ekstrak Sargassum sp sebagai pupuk organik, pemanfaatan lahan sempit, pemanfaatan kotoran kambing yang selama ini justru menjadi sampah dilingkungan tempat tinggal. Poin penting yang disampaikan ialah bagaimana memanfaatkan lahan pekarangan yang sempit menjadi lahan yang sangat 
bermanfaat untuk memenuhi kebutuhan keluarga. Pada kegiatan penyuluhan ini terlihat antusiasme masyarakat sasaran yang sangat tinggi. Antusiasme ini muncul dari pengalaman harus membeli kebutuhan keluarga pada saat musim kemarau. Terlebih lagi ada yang menginisiasi untuk memulai memanfaatkan lahan pekarangan yang mereka miliki.

Peserta yang hadir dalam kegiatan penyuluhan berasal dari berbagai latar belakang, mulai dari petani, buruh tani, peternak dan siswa SMU (karena sekolah sudah mulai libur). Keberagaman latar belakang membuat sinergi untuk saling membantu dalam penyediaan bibit mapun media tanam kedepannya. Sehingga dengan adanya kegiatan diskusi tersebut masyarakat dapat langsung mengaplikasikan ide dan gagasan yang disampaikan oleh tim pengabdian pada masyarakat.

Masyarakat sasaran sangat antusias mengikuti kegiatan diskusi yang diadakan. Hal ini terlihat dari pertanyaan yang diajukan terkait dengan kegiatan diskusi. Beberapa pertanyaan yang muncul diantaranya ialah Sargassum itu apa? Bagaimana cara aplikasinya? Kapan diaplikasikan? Dan lain sebagainya. Menurut pengakuan masyarakat Sargassum sp bukan merupakan jenis yang tidak pernah mereka lihat. Namun sebaliknya Sargassum sp merupakan salah satu jenis tumbuhan laut yang pernah mereka konsumsi sebagai tambahan pada laut bumbu kuning (Ikan laut bumbu kuning. Selain itu, mereka baru mengetahui bahwa apa yang pernah mereka konsumsi dapat dijadikan sebagai pupuk untuk tanaman.

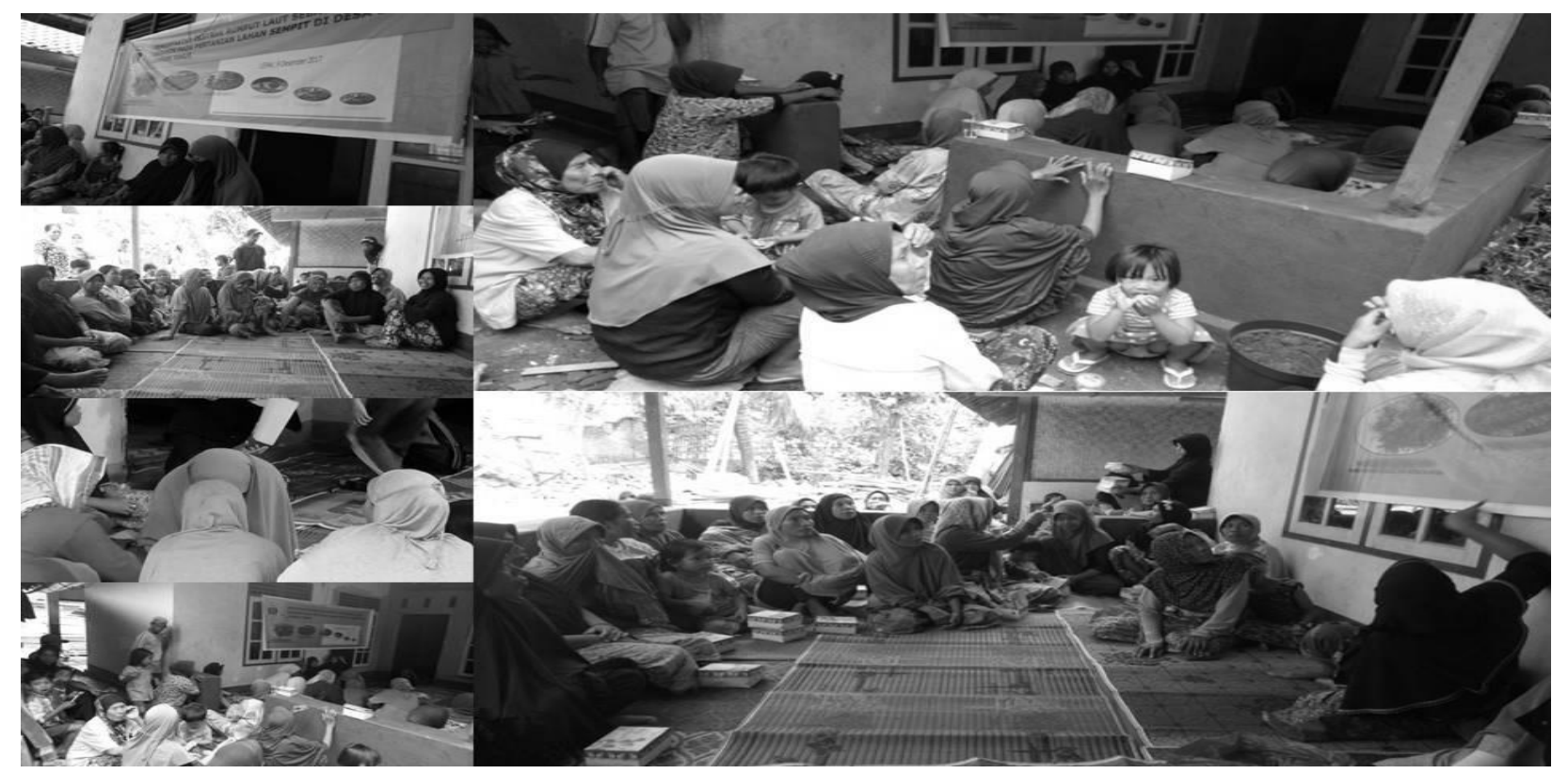

Gambar 1. Transfer ilmu pengetahuan pada masyarakat sasaran dengan metode ceramah

\section{Partisipasi Peserta \\ Persiapan Media Tanam}

Masyarakat yang menjadi sasaran kegiatan pengabdian masyarakat dilibatkan secara langsung untuk menyiapkan media tanam yang akan digunakan. Media yang digunakan pada kegiatan pengabdian dengan memanfaatkan lahan sempit ini adalah media tanah. Meskipun demikian media yang digunakan bukan hanya tanah secara keseluruhan, tetapi merupakan percampuran dari berbagai bahan diantaranya tanah, pupuk kandang, pasir, dan pupuk anorganik standar. Selain itu, nantinya akan diaplikasikan pupuk organik berbahan dasar rumput laut.

a. Tanah

Tanah merupakan media utama pertumbuhan tanaman dan merupakan sumber nutrisi bagi tanaman. Oleh sebab itu keberadaan tanah sangat penting artinya bagi pertumbuhan tanaman, meskipun dapat digantikan dengan bahan lain.

b. Pupuk kandang

Pupuk kandang merupakan pupuk yang berasal dari kotoran ternak. Penggunaan pupuk kandang berfungsi sebagai sumber nutrisi tambahan bagi 
tanaman. Meskipun semua jenis kotoran ternak dapat digunakan sebagai tambahan media tanam tetapi harus memperhatikan berbagai sifat dari kotoran ternak yang dihasilkan. Pada kegitan pngabdian ini pupuk kandang yang digunakan ialah pupuk kandang yang berasal dari kotoran kambing. Pemilihan jenis pupuk kandang ini mengingat kebanyak masyarakat sasaran termasuk peternak kambing, sehingga kedepannya relatif lebih gampang untuk membuat pupuk dari kotoran kambing.

c. Pasir

Penggunaan tanah dan pupuk kandang sebagai bahan atau media tanam memang memiliki banyak manfaat. Tetapi, jika hanya menggunakan kedua media tersebut kemungkinan media tanam akan menjadi pada sehingga susah untuk menyerap air dan dapat berakibat pada pembususkan tanaman.

\section{Penanaman}

Sebelum melakukan penanaman pada media tanam, maka media yang telah disipkan dalam pot disiram dan dibiarkan selama satu minggu. Proses ini bertujuan untuk memberikan kesempatan pada biji gulma yang pada media dapat tumbuh. Gulma yang tumbuh pada media tanam dibersihkan terlebih dahulu baru kemudian dilakukan penanaman. Jenis tanaman sayuran yang dijadikan sebagai percontohan ialah terung, tomat, cabai dan sawi.

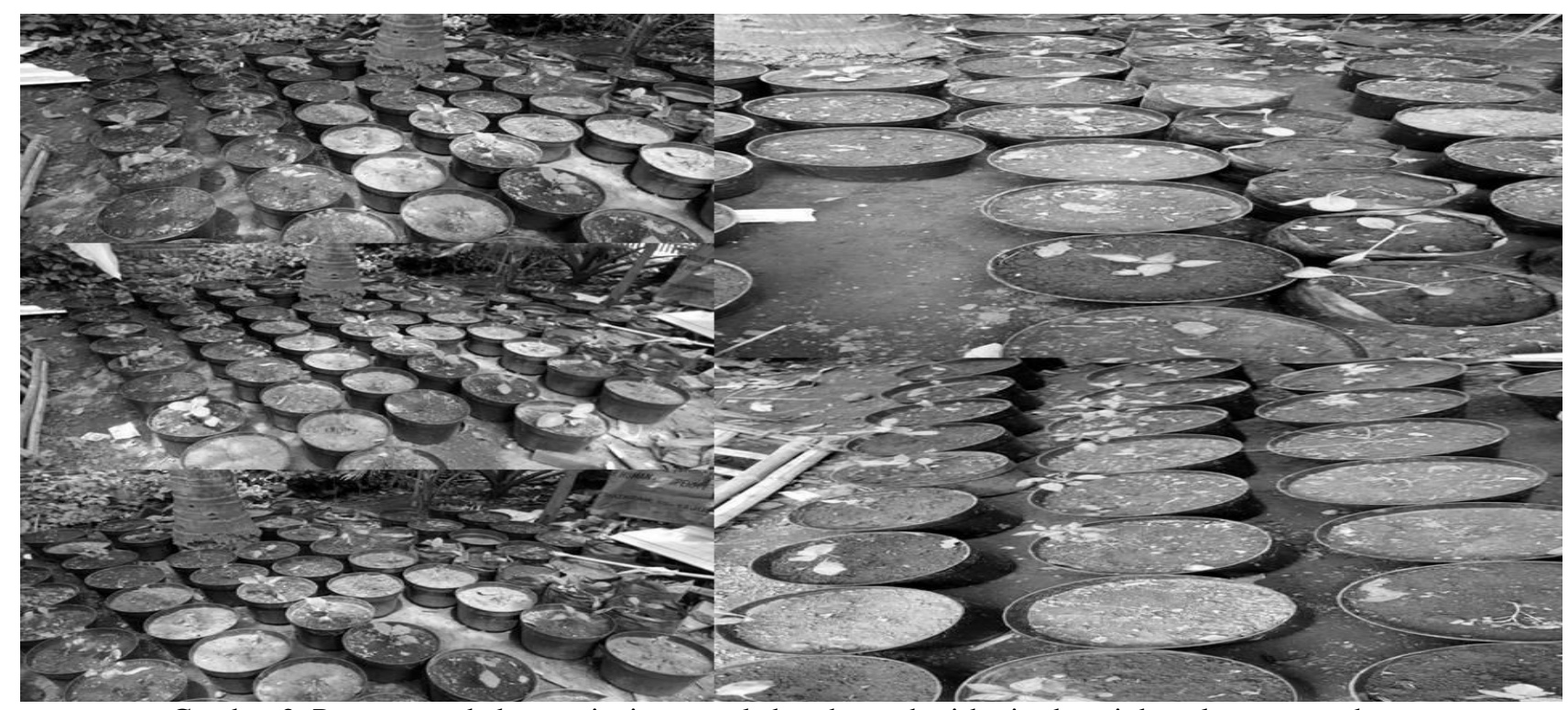

Gambar 2. Penanaman beberapa jenis sayur kebutuhan sehari-hari sebagai demplot percontohan

Pemilihan jenis tanaman yang ditanam disesuaikan dengan kebutuhan msing-masing dari masyaarakat sasaran. Setiap masyarakat memiliki keinginan yang berbeda terkait dengan jenis tanaman yang akan ditanaman. Keinginan masyarakat yang memananam jenis tanaman yang berbeda tidak mengurangi esensi dari upaya memanfaatkan lahan sempit. Bahkan menanam jenis tanaman yang berbeda setiap keluarga sangan dianjur sehingga memungkinkan untuk saling berbagai.

\section{Pembagian Pot Percontohan}

Pot yang telah ditanami dengan berbagai jenis sayuran diberikan kepada masyarakat sasaran kegiatan pengabdian. Pemberian pot percontohan bertujuan untuk melibatkan msyarakat secara langsung dalam kegiatan pengabdian. Masyarakat tidak hanya diberikan ilmu pengtahuan melalui kegiatan pengabdian tetapi langsung terlibat aktif. Selain memelihara pot percontohan yang telah diberikan, beberapa peserta memiliki inisiatif sendiri untuk memperbanyak jumlah pot untuk dipelihara. Inisiatif dari masyarakat ini merupakan bukti bahwa penggunaan lahan sempit memiliki manfaat yang cukup besar, ditambah lagi dengan hasil yang telah dilihat di Dusun Roton yang memanfaatkan lahan sempit dengan dana mandiri. 


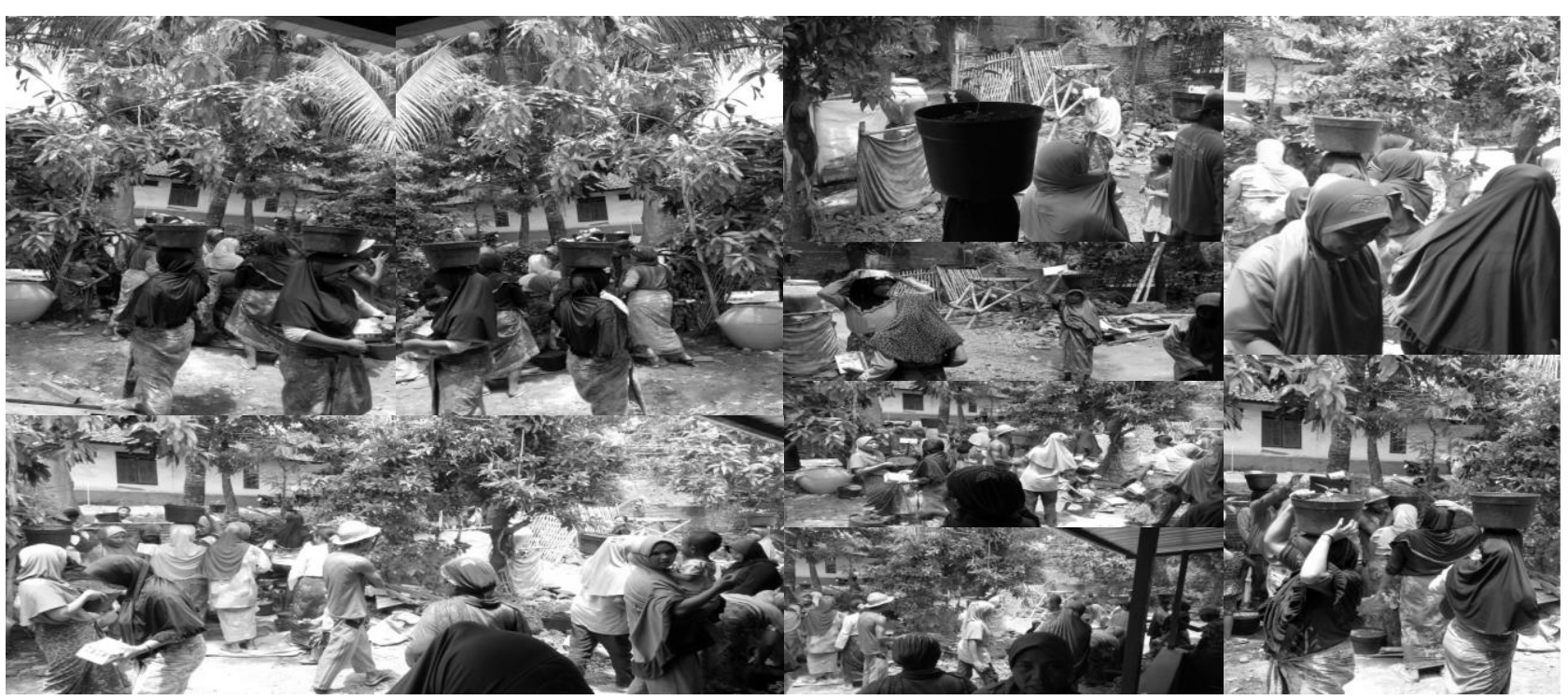

Gambar 3. Pembagian pot yang telah ditanamai kepada masyarakat sasaran.

\section{Pemeliharaan}

Budidaya tanaman sayur dalam pot bukan setelah tanam lalu ditinggalkan begitu saja. Tetapi kegiatan bertanam ini juga memerlukan perawatan sampai tanaman siap dipanen. Masyarakat sasaran yang telah medapatkan pot yang berisi tanaman sayuran bertanggung jawab untuk melakukan pemeliharaan. Pemeliharaan yang dilakukan meliputi penyiraman, pembersihan gulma dan pemupukan standard serta penyemprotan dengan ekstrak Sargassum sp.

Hasil pemeliharaan yang dilakukan oleh masyarakat menunjukkan hasil yang berbeda-beda pada setiap masyarakat sasaran. Sebagian masyarakat gagal memlihara tanaman sampai menghasilkan buah atau sampai masa produksi tiba. Kegagalan ini umumnya disebabkan oleh tanaman yang dipeliharan dimakan oleh ayam atau kambing. Oleh sebab itu, kedepannya perlu dilakukan upaya supaya tanaman aman dari ayam dan kambing. Meskipun demikian beberapa masyarakat sukses memlihara tanaman sayuran sammpai masa panen tiba. Keberhasilan ini disebabkan karena peserta secara intensif disela-sela kesibukan memperhatikan tanaman pehiharaannya. Bahkan beberapa orang berinisiatif untuk memagari tanaman yang dipelihara.

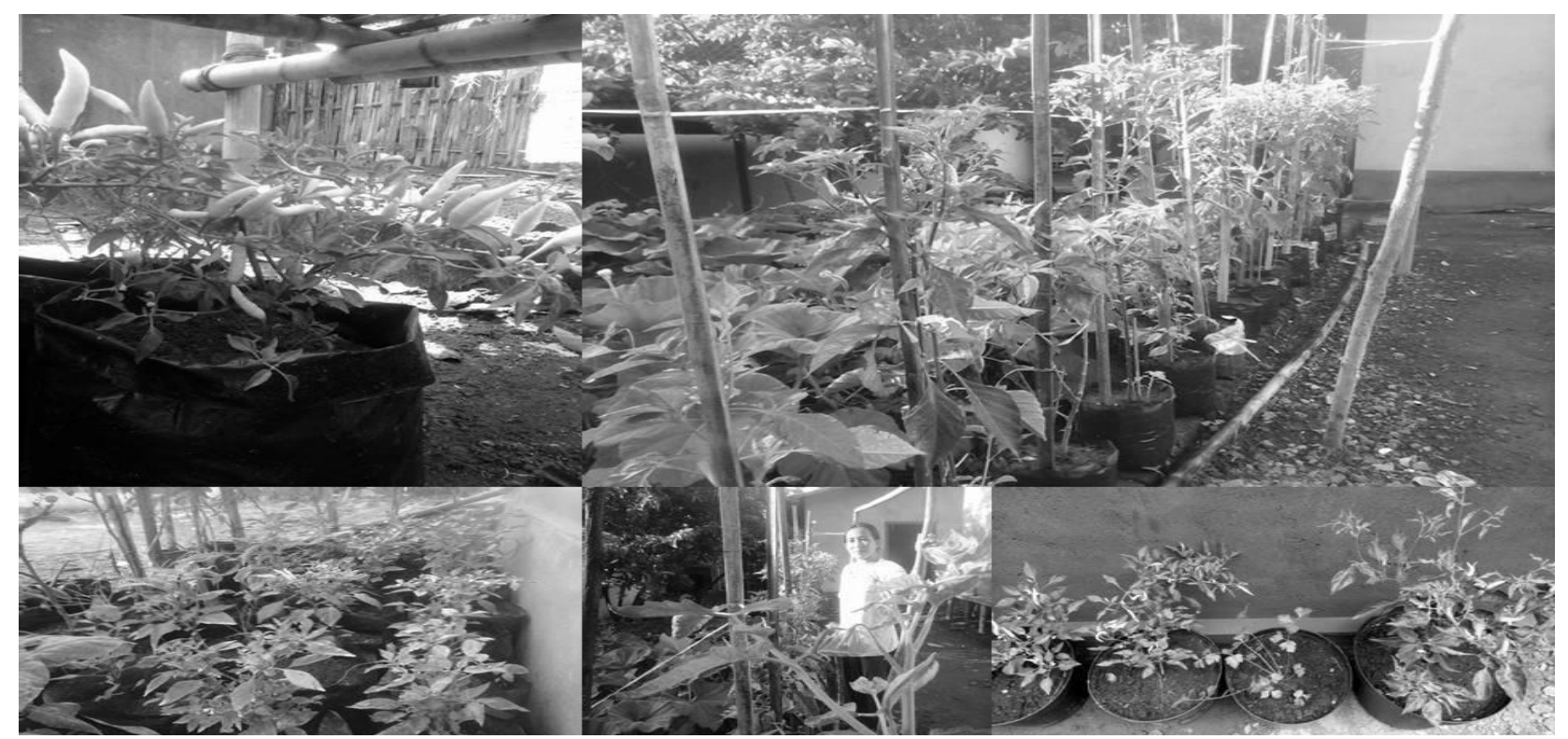

Gambar 4. Tanaman dalam pot pada demplot percontohan 


\section{Kesimpulan}

Berdasarkan hasil kegiatan pengabdian yang dilakukan di Dusun Bongkem, Desa Lepak, Kecamatan Sakra Timur dapat disimpulkan bahwa Hasil kegiatan pengabdian menunjukkan bahwa masyarakat sangat antusias mengikuti kegiatan diskusi, hal ini disebabkan karena Sargassum sp bukan jenis tumbuhan yang asing, tetapi mereka baru tahu bahwa tumbuhan tersebut dapat dijadikan sebagai pupuk. Selain itu, hasil pemeliharaan yang dilakukan oleh masyarakat sebagian menunjukkan hasil yang positif dan sebagaian yang lain tidak berhasil. Kegagalan disebabkan karena banyak faktor diantaranya: dimakan ayam dan kambing.

\section{Daftar Pustaka}

Abdul R , Rahmawaty, Budiati D, Said TJ. 2013. Sistem Pertanian Terpadu Di Lahan Pekarangan Mendukung Ketahanan Pangan Berkelanjutan Dan Berwawasan Lingkungan. Jurnal Online Jurnal online Pertanian Tropik Pasca Sarjana FP USU 1 (1): 1-8.

Ariningsih E, Rachman HPS. 2008. Strategi Peningkatan Ketahanan Pangan Rumah Tangga Rawan Pangan. Analisis Kebijakan Pertanian. Pusat Analisis Sosial Ekonomi dan Kebijakan Pertanian. Badan Penelitian dan Pengembangan Pertanian 6(3): 239-255.

Ashari, et al. 2012. Potensi Dan Prospek Pemanfaatan Lahan Pekarangan Untuk Mendukung Ketahanan Pangan. Forum Penelitian Agro Ekonomi 30 (1): 13-30.

Kaputra I, 2013, Alih Fungsi Lahan, Pembangunan Pertaniandan Kedaulatan Pangan, Strukturasi Vol. 1, No. 1., Juli 2013 (25-39)

Nikmatullah A., Mursal Ghazali, Rina Kurnianingsih, Mulyawarni and Sunarpi, 2014, Kemampuan Extract Aquadest Beberapa Makro Alga Pulau Lombok, Indonesia Dalam Merangsang Pertumbuhan Tanaman Padi, Agroteksos Volume 24 Nomor 3, Desember 2014.

Oelviani R dan Utomo B., 2015, Sistem pertanian terpadu di lahan pekarangan mendukung ketahanan pangan keluarga berkelanjutan: Studi kasus di Desa Plukaran, Kecamatan Gembong, Kabupaten Pati, Jawa Tengah, Pros Sem Nas Masy Biodiv Indon Volume 1,
Nomor 5, Agustus 2015 ISSN: 2407-8050 Halaman: 1197-1202

Rosidah I.S., 2014, Pemanfaatan Lahan Dengan Menggunakan Sistem Hidroponik, Jurnal Universitas Tulungagung BONOROWO Vol. 1.No.2

Saleim H.P, 2011, Kawasan Rumah Pangan Lestari (KRPL): Sebagai Solusi Pemantapan Ketahanan Pangan, Makalah Disampaikan pada kongres ilmu pengetahuan Nasional (KIPNAS) Jakarta, 8-10 November 2011.

Siswati L. 2012. Pendapatan Petani Melalui pertanian Terpadu Tanaman Hortikultura Dan Ternak Di Kota Pekanbaru. Jurnal Fakutas Peternakan Unand 14:13-21

Sutanto R, 2002, Penerapan pertanian organik, pemasyarakatan dan Pengembangannya, Kanisius Yogyakarta 